\title{
A Clinical and cost comparison of cancer and non- cancer patients in palliative care
}

\section{Palyatif bakımda kanserli ve kanser olmayan hastaların klinik ve maliyet karşılaştırması}

\author{
Hamit Celikk ${ }^{1}$, Behçet Varıșlı ${ }^{2}$, Ahmet Yardım³ ${ }^{3}$, Sinan Yıldırım ${ }^{1}$, Mesude Kisli ${ }^{4}$
}

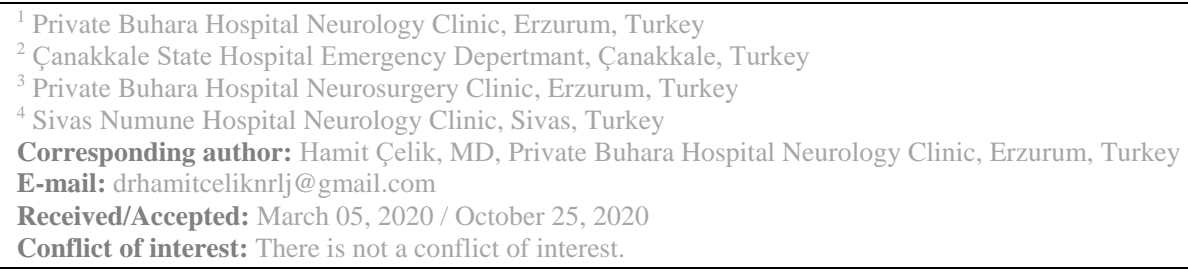

\section{SUMMARY}

Objective: As in many parts of the world, palliative healthcare systems were initially established for the care of cancer patients, but expanded in time to cover other patients, as well. The aim of this study was to compare cancer and non-cancer patients receiving palliative care in the city of Çanakkale, Turkey, in terms of their clinical and demographic data, treatment times, and costs.

Method: All patients hospitalized in Çanakkale State Hospital Palliative Care Unit between December 01, 2016 and December 01, 2017 were included in our study. Their demographic data, diagnoses, lengths of stay, mortality rates, and treatment costs were recorded retrospectively.

Results: The study included a total of 415 patients, of which 187 (45.1\%) were female. Mean age was 76.54 and the range of distribution was 24-100. Mortality developed in $162(39 \%)$ of all patients and $253(61 \%)$ were discharged. A comparison of cancer and non-cancer patients showed that mean age of the former group was significantly lower. Hospital stay and treatment costs of patients hospitalized for diseases other than cancer were found to be significantly higher than those of cancer patients.

Conclusions: Palliative care is an approach that improves the quality of life of patients and their families. As the costs of healthcare in intensive care units kept increasing, palliative care centers started to spread worldwide. Palliative care service includes cancer patients as well as those suffering from chronic neurological diseases and geriatric patients. Palliative care services are expected to increase and expand gradually as the average life increases. Therefore, it deserves better attention as a discipline.

Keywords: Palliative care, mortality, treatment costs

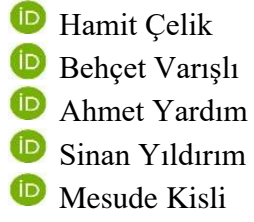

ORCID IDs of the authors:

H.Ç. 0000-0002-8654-2518

B.V. 0000-0002-2346-1112

A.Y. 0000-0003-1134-6050

S.Y. 0000-0001-8191-168X

M.K. 0000-0002-5212-297X

\section{ÖZET}

Amaç: Sağlık sistemlerine dünyanın bir çok yerinde olduğu gibi ülkemizde de kanser hastalarının bakımı için başlayan palyatif bakım ünitelerinin hizmet alan hasta grubunu giderek kanser dişı hastalıklarla ilişkili bakım alan hastalar olușturmaya bașlamıștır. Biz bu çalıșmamızda; Çanakkale ilindeki Palyatif Bakım (PB) hizmeti alan kanser tanılı hastaları, kanser dışı tanıları olan hastalar ile klinik ve demografik verilerini, tedavi sürelerini ve maliyetlerini karșılaștırmayı amaçladık. 
Yöntem: Çalışmamıza 01 Aralık 2016-01 Aralık 2017 tarihleri arasında Çanakkale Devlet Hastanesi PB Servisinde yatan tüm hastalar dahil edildi Hastalar geriye dönük olarak demografik verileri, tanıları, yatış süreleri, mortalite oranları ve tedavi maliyetleri kaydedildi.

Bulgular: Çalışma kapsamına alınan 415 hastanın 187 (\%45,1)'si kadındı. Yaş ortalaması 76,54, dağılım aralığı 24-100 idi. Tüm hastaların 162 (\%39)'isinde mortalite gelişmiş, 253 (\%61)'ü taburcu olmuştur. Kanser hastaları ile kanser dışı nedenlerden yatan hastaları karșılaștırdığımızda kanser hastalarının yaş ortalamasının anlamlı șekilde düşük olduğu görülmektedir. Kanser dışı nedenlerle yatan hastaların hastane yatış süreleri ve tedavi maliyetleri hastalarına göre anlamlı derecede yüksek tespit edilmiștir.

Sonuç: Palyatif Bakım tanımı itibariyle hastaların ve ailelerinin yaşam kalitesini artıran bir yaklaşımdır. Son dönem yükselen yoğun bakım kaynaklı maliyetleri azaltmak amacıyla dünya genelinde Palyatif Bakım merkezleri yaygınlaştırılmışıı Palyatif Bakım hizmetini kanser hastaları yanında, kronik nörolojik hastalıklar ve geriatrik hastalarıda kapsamaktadır. Artan ortalama ömür nedeniyle PB servislerine olan ihtiyacın giderek artacağı ve bu disipline daha fazla önem verilmesi gerektiğini anlașılmaktadır.

Anahtar sözcükler: Palyatif Bakım, mortalite, tedavi maliyeti

\section{INTRODUCTION}

World Health Organization (WHO) defines palliative care as "an approach to improve the quality of life for patients and their families by way of early identification, correct evaluation, and treatment of a number of physical, psychological, social, and mental problems associated with lifethreatening diseases." 1,2 The first modern center of palliative care was founded in the United Kingdom in 1967. And the first PC center in Turkey, in the modern sense, was established for cancer patients in 1993 by the Turkish Oncology Foundation. ${ }^{3}$ Since the project titled PALLIATURK was launched in 2009 as part of the National Cancer Control Program, an increasing number of PC centers were opened. ${ }^{4}$ The social security institution of Turkey started to cover palliative care services in medical insurance reimbursements in 2014. ${ }^{5}$ As a result, palliative care centers started to grow in number and bed capacity from that date on, especially in public hospitals. ${ }^{6}$ As of 2018, there are 410 medical centers providing palliative care service in Turkey with a capacity of 5,481 beds. ${ }^{7}$

Palliative care does not address a specific condition. From the diagnosis of any chronic and advanced disease, it determines a plan of care for the patient and family, including the end-of-life circumstances. In patients with cancer, dementia, Alzheimer's, and cerebrovascular disease sequels, palliative care is not identical to (or, synonymous with) terminal care, but includes it. ${ }^{8,9}$ Education is provided for the family of the patient under care. Death is considered a natural outcome and no specific efforts are made to delay it. The aim of palliative care is to provide comfort to the patient and support to the family in this process. ${ }^{10}$

Palliative care centers were first opened primarily for the care of cancer patients in Turkey, as was the case in many parts of the world. But in time, they came to serve non-cancer patients, as well. ${ }^{11}$ Currently, the care of non-cancer patients makes up the largest part of both their work and costs. The aim of this study was to compare cancer and noncancer patients receiving palliative care in the city of Çanakkale, Turkey, in terms of their clinical and demographic data, treatment times, and costs.

\section{MATERIAL AND METHODS}

All patients hospitalized in Çanakkale State Hospital Palliative Care Unit between December 01, 2016 and December 01, 2017 were included in our study. Their demographic data, diagnoses, lengths of stay, mortality rates, and treatment costs were recorded retrospectively from the automated hospital system.

\section{Statistical Analysis:}

The data were recorded with the SPSS 17.0 software package. From among the continuous variables, those with a normal distribution were taken as the mean \pm standard deviation and those without as the median (minimum-maximum) and categorical variables were expressed in numbers and percentages. For the significance of the difference between the group mean values in continuous variables, Mann Whitney-U test was used in groups without a normal distribution and Stundent t-test was used in groups with a normal distribution. Pearson's chi-square and Fisher's exact tests were used for the significance of the difference between categorical variables. All calculations were made in two ways. Statistical significance was defined at $\mathrm{p}<0.05$ threshold.

\section{RESULTS}

The study included a total of 415 patients, of which $187(45.1 \%)$ were female. Mean age was 76.54 and the range of distribution was 24-100. Mortality developed in 162 (39\%) of all patients and 253 
(61\%) were discharged. A review of the admission times revealed that it was it was most common in January and February (Figure 1) and in the afternoon, at 14:00 (Figure 2). While 45 (10.8\%) of the 415 patients included in the study were hospitalized with the diagnosis of cancer, 370 $(89.2 \%)$ were in palliative care for non-cancer reasons. Of the cancer patients, $32(71 \%)$ were male and 13 (29\%) were female. Among the patients receiving palliative care for non-cancer diseases, 196 (53\%) were male and 174 (47\%) were female. As a result, it was observed that the mean age of patients hospitalized with cancer was 71.4 years, whereas of those in care with noncancer diagnoses it was 77.17 years. The average length of hospitalization in days was 7.89 for patients with a cancer diagnosis and 19.34 for the others. The average treatment costs of patients receiving palliative care were found to be TL $5,412.26$. The costs of patients with cancer were TL 2,358.78 and the costs of patients with noncancer conditions were TL 5,783.63.
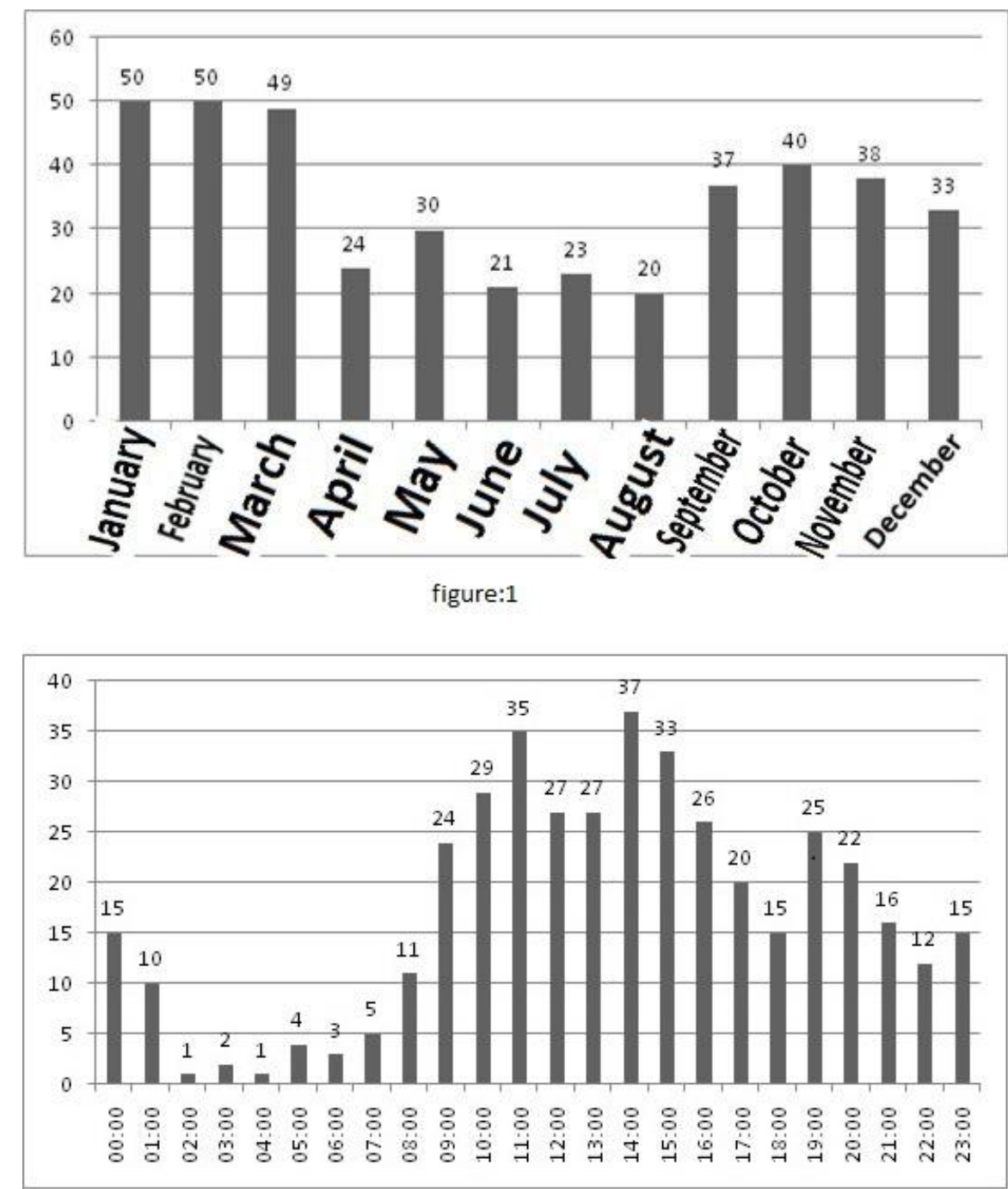

figure:2

A comparison of cancer and non-cancer patients showed that mean age of the former group was significantly lower (p: 0.005). Length of stay and treatment costs of patients hospitalized for diseases other than cancer were found to be significantly higher than those of cancer patients (p: 0.004). (Table 1)
A comparative analysis in terms of mortality suggested shorter hospitalization and lower treatment costs for terminal patients, but no statistically significant difference was found (p: 0.055 , p: 0.055 ). No significant difference was found between the two groups in terms of sex or diagnosis. (Table 2) 
Table 1

\begin{tabular}{|c|c|c|c|c|}
\hline & & Cancer Patients (n:45) & $\begin{array}{l}\text { Patients Hospitalized for Non- } \\
\text { Cancer Reasons (n:370) }\end{array}$ & $\mathrm{p}$ value \\
\hline \multirow{2}{*}{ Sex } & Male (n:228) & $32(14.04 \%)$ & $196(85.96 \%)$ & \multirow{2}{*}{$0.021 *$} \\
\hline & Female (n:187) & $13(6.95 \%)$ & $174(93.05 \%)$ & \\
\hline \multirow{2}{*}{ Mortality } & Exitus (n:162) & $21(12.96 \%)$ & $141(87.04 \%)$ & \multirow{2}{*}{$0.266^{*}$} \\
\hline & Survived (n:253) & $24(9.48 \%)$ & $229(90.52 \%)$ & \\
\hline \multicolumn{2}{|l|}{ Age } & $71.4 \pm 11.02$ & $77.17 \pm 13.08$ & $0.005^{* *}$ \\
\hline \multicolumn{2}{|l|}{ Costs } & $2,358.78 \pm 2,242.25$ & $5,783.63 \pm 7,790.55$ & $0.004 * *$ \\
\hline \multicolumn{2}{|c|}{ Hospital Stay in Days } & $7.89 \pm 7.50$ & $19.34 \pm 26.06$ & $0.004 * *$ \\
\hline
\end{tabular}

*Pearson Chi-square, **Mann Whitney-U

Table 2

\begin{tabular}{|c|c|c|c|c|}
\hline & & Died (n:162) & Survived (n:253) & $\mathrm{p}$ value \\
\hline Sey & Male (n:228) & $88(14.04 \%)$ & $140(85.96 \%)$ & $0830 *$ \\
\hline$\pi \lambda^{2}$ & Female (n:187) & $74(6.95 \%)$ & $113(93.05 \%)$ & 0.057 \\
\hline & Cancer (n:45) & $21(12.96 \%)$ & $24(9.48 \%)$ & 0 266* \\
\hline Dlagniosis & Other (n:370) & $141(87.04 \%)$ & $229(90.52 \%)$ & $0.200^{\circ}$ \\
\hline Age & & $77.79 \pm 11.69$ & $75.75 \pm 13.72$ & $0.122 * *$ \\
\hline Costs & & $4,532.99 \pm 4,346.60$ & $5,975.27 \pm 8,873.05$ & $0.055 * *$ \\
\hline Hospital St & $\mathrm{y}$ in Days & $15.16 \pm 14.54$ & $19.98 \pm 29.68$ & $0.055 * *$ \\
\hline
\end{tabular}

*Pearson Chi-square, **Mann Whitney- $U$

\section{DISCUSSION}

According to the last census data in Turkey, the percentage of the population above 65 years is $8.8 \% .{ }^{12}$ However, the average life expectancy is 78.3 , with 75.6 years for men and 81 for women. ${ }^{13}$ An analysis of the data from the study patients in terms of age distribution, the mean age was found to be 76.5 years and the range of distribution was 24-100. Mortality developed in 162 (39\%) of the study patients. Considering the clinical features and disease burdens of patients followed up in palliative care services, high mortality rates can be expected. Studies in the literature, involving larger numbers of patients through longer time periods, also suggest high mortality rates. ${ }^{14}$

There is a growing need for palliative care units and centers, both in Turkey and in the world at large, in parallel with the number of elderly population and, as a result, the frequency of chronic disease. A large number of symptoms that are hard to keep under control coexist in the course of the cancer disease, after its treatment, and during the terminal stage. ${ }^{15}$ As a result, cancer patients make up the group that receives and benefits from palliative 
care units more and more often than the rest. This situation forged a close link between cancer disease and palliative care. Several studies conducted in Turkey showed that cancer patients made up a significant ratio of all patients receiving palliative care. ${ }^{16,22}$ In this study, we compared cancer and non-cancer patients receiving palliative care in terms of their clinical and demographic data, treatment times, and costs of care and treatment.

The most common symptoms in patients hospitalized in palliative care units are difficulty in oral intake, poor general condition, anorexiaweight loss, and weakness-fatigue. In addition to these symptoms, complaints of pain are prominent in cancer patients. ${ }^{15}$ A comparison of cancer and non-cancer patients showed that the mean age of the former group was significantly lower. It was 71.4 years in patients diagnosed with cancer and 77.2 years in the non-cancer group. Similar studies in the literature also show that cancer patients make up a younger age group. ${ }^{17,20}$ As for the distribution per sex, in the group with cancer diagnosis there were $32(71 \%)$ male patients, whereas 196 (53\%) were male in the non-cancer group. Other studies in the literature are consistent with our study in the findings that men benefit more from palliative care services, especially if they are cancer patients. $16,17,20$

Cancer appeared to be a negative factor in the length of hospitalization in the palliative care units, however cerebrovascular disease, hypertension, and diabetes mellitus were found to be positive factors. As for conditions such as advanced pressure sores, they are treatable once detected, but they certainly factor in the length of stay. ${ }^{17,23}$. In our study, the mean length of hospitalization in palliative care was found as 7.89 days for patients diagnosed with cancer, in other words, much shorter than the hospitalization times of non-cancer patients which was found as 19.34 days on average. The short duration of hospitalization in cancer patients was linked to the fact that long-term care was mostly not needed in chronic diseases.

Palliative care is an approach that improves the quality of life of patients and their families. ${ }^{1,2}$ It is closely followed and examined by health systems for the costs of practices that increase the quality of life. There are many studies on the costs of medical care provided at the end of life. ${ }^{24,25}$ In order to reduce the intensive care costs that increase in the end-of-life stage, many new palliative care centers were opened worldwide. ${ }^{26,27}$ Hospital stay and treatment costs of patients hospitalized for diseases other than cancer were found to be significantly higher than those of cancer patients.
In addition to cancer patients, others, especially geriatric patients with multiple chronic diseases receive palliative care. This indicates that the need for palliative care will continue to increase due to chronic non-cancer diseases as the population ages. Therefore, palliative care deserves better attention as a discipline.

\section{REFERENCES}

1. Bağ B. Almanya örneğinde sağlık sisteminde palyatif bakım uygulamaları. Turkish Journal of Oncology/Türk Onkoloji Dergisi. 2012;27(3).

2. World HealthOrganisation (WHO). Definition of palliativecare. Erişim Linki: Adres: Adress: https://www.who.int/cancer/palliative/definition/e $\mathrm{n} /$. access date: 01.01.2020.

3. Erbaycu AE. Terminal Hastalar ve Destek Tedavisi. Adres:

Adress:http://ghs.asyod.org/konular/2013-315.pdf. access date:: 01.01.2020.

4. Uslu FŞ, Terzioğlu F. Dünyada ve Türkiye'de Palyatif Bakim Eğitimi ve Örgütlenmesi. Cumhuriyet Hemşirelik Dergisi. 2015;4(2):81-90.

5. Kabalak AA. Türkiye'de Palyatif Bakım Çalışmaları. Turkiye Klinikleri Anesthesiology Reanimation-Special Topics. 2017;10(1):7-12.

6. Taș SŞ, Kahveci K. Uzun Süreli Yoğun Bakım Ünitesi ve Palyatif Bakım Merkezinde Hastane Enfeksiyonlarının Sürveyansı; 3 Yıllık Analiz. Çağdaş Tip Dergisi. 2018;8(1):55-9.

7. Adress: https://khgmozellikli.saglik.gov.tr/svg/palyatif.ph $\mathrm{p}$ access date: 14.01.2020.

8. WHO Definition Of Palliative Care. Adress: http://www.who.int/cancer/palliative/definition/en /. access date:i: 01.01.2020.

9. Elçigil A. Palyatif bakım hemşireliği. Gulhane Medical Journal. 2012;54(4).

10. Field MJ, Behrman RE. Patterns of childhood death In America. When Children Die: Improving Palliative and End-of-Life Care for Children and Their Families: National Academies Press (US); 2003.

11. Benli AR, Sunay D. Palyatif Bakım Merkezi ve Evde Sağlık Hizmetlerinin Birlikte Çalışması Örneği: Karabük. Ankara Medical Journal. 2017;17(3):143-50.

12.Adress: http://tuik.gov.tr/PreTablo.do?alt_ $\mathrm{id}=1059$ access date:01.01.2020.

13. Adress: http://www.tuik.gov.tr/ PreHaberBultenleri.do?id=30712 access date: 01.01.2020. 
14. Dincer M, Kahveci K, Doger C. An examination of factors affecting the length of stay in a palliative care center. Journal of palliative medicine. 2018;21(1):11-5.

15. Do Shoemaker LK, Estfan B, Induru R, Walsh TD. Symptom management: an important part of cancer care. Cleveland Clinic journal of medicine. 2011;78(1):25.

16. Al-Jamal Y, Soysal P . Bezmialem Vakıf Üniversitesi Dragos Hastanesi Palyatif Bakım Ünitesi Verileri. Geriatrik Bilimler Dergisi. 2019; 2(3): 89-86.

17. Yürüyen M, Tevetoğlu IÖ, Tekmen Y, Polat Ö, Arslan İ, Okuturlar Y. Palyatif Bakım Hastalarında Klinik Özellikler ve Prognostik Faktörler. Konuralp Tip Dergisi. 2018;10(1):74-80.

18. Bülbül Y, Ozlu T, Arinc S, Ozyurek B, Gunbatar H, Senturk A, et al. Assessment of palliative care in lung cancer in Turkey. Medical Principles and Practice. 2017;26(1):50-6.

19. Hacıkamiloglu E, Utku ES, Cukurova Z, Keskinkilic B, Topcu I, Gultekin M, et al. Community palliative care in Turkey: A collaborative promoter to a new concept in the Middle East. Journal of Public Health Management and Practice. 2016;22(1):81-8.

20. Özalp GŞ, Uysal N, Oğuz G, Koçak N, Karaca Ş, Kadıogulları N. Identification of symptom clusters in cancer patients at palliative care clinic. Asia-Pacific journal of oncology nursing. 2017;4(3):259.
21. Şenel G, Oğuz G, Koçak N, Karaca Ş, Kaya M, Kadıogulları N. Opioid use and the management of cancer patient pain in palliative care clinic. Ağr1The Journal of The Turkish Society of Algology. 2016;28(4):171-6.

22. Uysal N, Şenel G, Karaca Ş, Kadıŏulları N, Koçak N, Oğuz G. Symptoms seen in inpatient palliative care and impact of palliative care unit on symptom control. 2015.

23. Allman RM. Pressure ulcer prevalence, incidence, risk factors, and impact. Clinics in geriatric medicine. 1997;13(3):421-36.

24. Emanuel EJ, Ash A, Yu W, Gazelle G, Levinsky NG, Saynina O, et al. Managed care, hospice use, site of death, and medical expenditures in the last year of life. Archives of internal medicine. 2002;162(15):1722-8.

25. Riley GF, Lubitz JD. Long-term trends in Medicare payments in the last year of life. Health services research. 2010;45(2):565-76.

26. Kabalak AA, Öztürk H, Çağıl H. Yaşam sonu bakım organizasyonu: Palyatif bakım. Yoğun Bakım Dergisi. 2013;11(2):56-70.

27. Borasio GD. Translating the World Health Organization definition of palliative care into scientific practice. Palliative \& supportive care. 2011;9(1):1-2. 